\title{
1. The history of the distinction between international and non-international armed conflicts
}

The distinction between the two separated bodies of international law of IAC and NIAC was formalised when CA3 of the 1949 Geneva Conventions was drafted and created the distinct body of law of NIAC. Before 1949, international law only regulated armed conflicts between states or sovereigns. NIAC, ${ }^{1}$ on the other hand, were not regulated under international law. ${ }^{2}$ However, the distinction between internal armed conflicts (between the ruler and his subjects) and external armed conflicts (between rulers or states) has existed for hundreds of years. ${ }^{3}$ This chapter examines the historical roots of this distinction in the Western tradition, ${ }^{4}$ and explores the development of IHL from a body of law that applied only between states or rulers, into a law that applies also between states and non-state groups. Throughout the historical review, it is shown that states have always accepted that there is a fundamental difference between international wars and internal wars. The main reason for that difference was that states regarded internal wars as an inherently internal matter, on the basis that non-state groups were tantamount to criminal groups having no right, legal or moral, to fight against their rulers. This

1 Many of the terms that are used in this chapter, such as IAC, NIAC and armed conflicts were only coined in the 1949 Geneva Conventions. Therefore, they are used here only for the sake of convenience as factual descriptions and not as legal qualifications. At this stage, for the purposes of this chapter, IAC should be understood as armed hostilities between states and NIAC (also referred to as internal armed conflict or internal wars) is armed hostilities between states and non-state groups (usually rebels against the territorial state).

2 With the exception of belligerency, see discussion in Section 1.1.3.

3 For an excellent historical review, see Perna (2006), 1-60.

4 Due to the limited scope of this work only Western history is analysed, since the foundation of modern international law was mainly shaped by Western states. For examination of the Islamic tradition and its perspective on NIAC see Perna (2006), 72-74. For discussion with regard to Islam and IHL in general, see Cockayne (2002). 
perspective, although transformed and reshaped, still echoes to some extent in the contemporary distinction between IAC and NIAC.

\subsection{THE DISTINCTION BEFORE THE 1949 GENEVA CONVENTIONS}

Before the formulation of the 1949 Geneva Conventions, the law of war applied only between states. ${ }^{5}$ States considered internal armed conflicts to be internal affairs, which should be regulated under municipal law. ${ }^{6}$ Much has changed throughout the last few centuries: empires have risen and collapsed, religious wars have been vigorously conducted, and the modern state has developed. Nevertheless, one point has not changed: states and rulers have always acted on the basis that there is a difference between internal armed conflicts and international wars - a difference that justifies the application of different rules.

\subsubsection{Before 1648}

Before the development of modern international law, the law of the right to go to war (jus ad bellum) and the law of conduct of hostilities (jus in bello) were influenced by the religious affiliations of the belligerent sides. $^{7}$ In the first centuries CE, some Christian leaders tried to stop Christians from becoming soldiers. ${ }^{8}$ However, with the commencement of the Crusades at the beginning of the eleventh century, the Church acknowledged that it could use warfare for its own purposes. ${ }^{9}$ Accordingly, the Church aimed to regulate both jus ad bellum and jus in bello between different Christian groups (i.e. states versus states or kings versus kings) and between Christian groups and non-Christian groups ('heathens'). The basic theological principle was that Christians deserve

5 Bartels (2009), 44-48; Cassese (2008A), 111, 113-114.

6 Bugnion (2003), 12-13; see also Sivakumaran (2012), 20-29 (examining domestic regulation of internal armed conflicts via instructions and agreement in the nineteenth and early twentieth centuries). But see discussion regarding the doctrine of belligerency in Section 1.1.3.

7 It should be noted that until the twentieth century, jus ad bellum and jus in bello were considered to be inherently connected. Interestingly enough, although the Latin terms convey a sense of antiquity, these terms were only coined in the 1930s. See in general: Kolb (1997).

8 MacCulloch (2010), 156-157.

9 Ibid., 382. 
better treatment than heathens. ${ }^{10}$ The most notable example of this principle was the decision of the Church in 1139 to ban the use of the crossbow against Christians but to allow its use against heathens. ${ }^{11}$ As time progressed, more rules such as proportionality and distinction have been developed, and adherence to these rules was considered a condition for waging a just war. ${ }^{12}$

The Christian understanding of internal wars was based on the theological principle that the authority of Christian rulers is derived directly from God. This principle was based on a passage from Romans, where Paul pronounced the divine right of the authorities, ${ }^{13}$ and was developed throughout the years by Christian scholars. ${ }^{14}$ Based on this principle, a rebellion against a ruler could almost never be classified as a 'just war'. ${ }^{15}$ Since rebels did not have authority to use force against legal rulers, they could not fulfil the basic conditions of the 'just war' doctrine, such as 'just cause' and 'just intention'.16 Accordingly, the Church dictated that rebels should be treated as heathens. ${ }^{17}$ In the rare cases that rebellion could be justified, limitations on the conduct of hostilities were placed only on the rebels as they had to avoid causing greater harm than the harm inflicted by the rulers. ${ }^{18}$

10 Bartels (2009), 42.

11 It should be mentioned that the prohibition on the use of the crossbow against Christians was never adhered to: see Strickland (1996), 72 and the sources cited therein at notes 82-83; see also Blum (2010), 75, note 8.

12 O'Brien (1981), 37 and 137.

13 St. Paul, The Holy Bible, passage from Romans 13:1.

14 Perna (2006), 1-9.

15 Interestingly, for Aquinas, rebellions could be justified in specific situations: 'A tyrannical government is not just because it is directed not to the common good, but to the private good of the ruler ... Consequently there is no sedition in disturbing a government of this kind, unless indeed the tyrant's rule be disturbed so inordinately, that his subjects suffer greater harm from the subsequent disturbance than from the tyrant's government', see T. Aquinas, Summa Theologica, Second Part of the Second Part, Question 42, Article 2. However, it should be noted that Aquinas claimed that even rebellions must be conducted by public officials and not individuals. Finally, it should be also noted that Aquinas did not formulate any rules that should be applied during such rebellions.

16 Perna (2006), 3-7.

17 Johnson (1981), 49-59. The notion that rebellions are an offence to God and rebels should be treated as heathens was echoed even in the sixteenth century in the works of the Spanish international jurist Balthazar Ayala (15481584), see discussion in Perna (2006), 15-16.

18 Aquinas, supra note 15. 
The evolution of Protestantism did not, initially, change the attitude towards internal wars. Luther's hostility towards rebellions was based on the biblical interpretation that the authority of the ruler is derived from God. ${ }^{19}$ He refused to consider the establishment of any rules to judge rebels and allowed the use of unlimited force against them. ${ }^{20}$ However, in the sixteenth century, in the midst of the struggle between Catholics and Protestants, Christian perspectives with regard to internal wars began to shift. It was then crucial, for Catholics and Protestants alike, to find a theological justification for rebellion against a prince with the opposite faith. Accordingly, the Catholic Church claimed that rebelling against a Protestant prince is justified since it entails obedience to a higher law and the punishment of the rebel prince. ${ }^{21}$ On the Protestant side, Calvin and later Knox also developed a theory that justified rebellions as an extreme measure. $^{22}$ However, according to Knox, even justified rebellions were not placed under any limitations with regard to the conduct of hostilities. $^{23}$

Though it should be noted that there could be a distinction between Christian theology that was used for political motives in order to justify the rulers' authority and other Christian approaches that were willing to acknowledge the just cause of rebellion in certain circumstances, ${ }^{24}$ the trend was clear: international wars were appreciated as distinct from internal wars and the Church, in general, allowed rulers to use unlimited power in internal wars in comparison to international wars. The main reason behind the distinction between internal and international wars was based on the religious view that rulers had a divine right to rule and therefore rebels did not have the right to use force; they were to be considered heathens or simple criminals.

\footnotetext{
19 Luther (1971), 101-102.

20 Nevertheless, Luther did approve rebellions of Christian princes against the Pope and the Emperor, see Gritsch (1972), 52-53.

21 Ramsey (1996), 115-116.

22 It should be noted that Calvin, similarly to Aquinas and Luther, argued that rebellions can be just only when they are conducted by people in an official capacity and not by individuals. See discussion in Perna (2006), 7-9.

23 Knox (1971), 108-111; Perna (2006), 8.

24 See for example Aquinas's approach, supra note 15.
} 


\subsubsection{8-1800s}

The Westphalia Peace Agreement of 1648 is considered the cornerstone of the creation of modern sovereign states and international law. ${ }^{25}$ Religious regulation of the law of war had begun to move aside in favour of modern international law that aimed to regulate both jus ad bellum and jus in bello. Nevertheless, the idea that only states had a right to use force internally as well as externally continued to be dominant under international law. However, in contrast to the period before 1648, the idea that humanitarian norms should protect victims of internal wars had begun to grow. Indeed, as we shall see below, these two sides of the same coin the application of humanitarian norms without acknowledging the nonstate groups' belligerency rights - will remain the main reason behind the creation and expansion of applicable law to internal wars on the one hand, and the continuation of the distinction between NIAC and IAC on the other hand.

The secular idea that only states have a right to use force on the one hand, and that some humanitarian norms should apply even in NIAC on the other hand, has roots in different theories of the social contract of that time. ${ }^{26}$ Although these theories vary considerably, they have two aspects in common. First, states derive their authority from the consent of their subjects. This consent entails the waiver of individuals' rights to use force and the legitimisation of the state's exclusive right to use force. ${ }^{27}$ Second, all individuals have rights that the sovereign must respect. ${ }^{28}$ Translating these ideas to the context of armed conflict means that only the sovereign has a right to use force and that the use of force by non-state groups is considered a criminal offence. However, when the sovereign ceases to protect and maintain his subjects' rights, the subjects have legitimate grounds to raise arms against their sovereign. ${ }^{29}$

Hand in hand with development of social contract theories, the notion of sovereignty also started to develop (in the aftermath of the formation

25 Gross (1948), 26. But see Lowe (2007), 9-10.

26 For general review of these theories in the context of IHL, see Perna (2006), 9-13.

27 Johnson (2010), 159; Cellini (1997), 847; the other side of the coin was the use of this theory in justifying rebellions in cases where the sovereign did not fulfil his duties towards the civilians, see Tate (1965), 375.

28 E.g. Hobbes (1957), 144-145 (arguing that the sovereign must protect his subjects. When the sovereign cannot maintain his duty and turns into an oppressor, he loses his sovereign right and his erstwhile subjects are free from any duty of loyalty to him).

29 E.g., ibid.; see also Neff (2005), 254. 
and consolidation of a system of territorial states). ${ }^{30}$ According to the doctrine of state sovereignty, the authority to regulate all aspects in the territorial state is vested in the sovereign. ${ }^{31}$ The sovereign has sole legitimacy to use internal and external force. ${ }^{32}$ Since all sovereigns were considered equal, rules regarding jus ad bellum and jus in bello had to be developed in order to regulate the relationship between these equal sovereigns. Rebels, on the other hand, did not have any legitimate right to use force. Since rebellions against the sovereign were considered internal matters and as hampering the security and order of society, ${ }^{33}$ the sovereign was free from constraints in suppressing rebellion. ${ }^{34}$ The attitude towards rebellions was 'a logical expression of the basic idea of the sovereign state, exercising exclusive control over territory'. ${ }^{35}$ Nevertheless, as expressed in Emmerich de Vattel's writing, the idea that some forms of internal wars should be regulated under international law had started to develop

Emmerich de Vattel's writing in the eighteenth century combined respect for sovereignty on the one hand, and humanitarian considerations derived from natural law on the other. ${ }^{36}$ Vattel, much like the international jurists who preceded him, argued that the law of war applies only between states. However, Vattel argued that the law of war should apply to internal wars in the form of civil wars that resemble international wars (for example where the state is divided into two parties without any legitimate sovereign). ${ }^{37}$ Other forms of internal war, such as rebellions, were not regulated under law as they were considered crimes

30 Perna (2006), 13-15.

31 Zick (2005), 257-258. See also in general Philpott (2010).

32 Weber (1958), 78.

33 Hinsley (1986), 126; Röling expresses this idea from a similar angle and argues that the crux behind states' approaches towards rebellions 'was the safeguarding of the existing monarchies by collective measures against revolution', see Röling (1976), 149.

34 Perna (2006), 13-14.

35 Falk (1971), 13.

36 But see Moir (2002), 3 (arguing that this scholarly development 'was based almost exclusively on the character of the conflicts and the fact that both were often of a similar magnitude, rather than any overriding humanitarian concern to treat the victims of both equally').

37 Vattel (1758), Book III, Chapter XVIII, [292]-[295]. This approach will echo 100 years later in the doctrine of belligerency, see discussion in Section 1.1.3. 
against the state. ${ }^{38}$ Nevertheless, even in rebellions, sparks of humanitarian considerations can be identified in his work in the shape of advice to refrain from excessive and cruel punishment. ${ }^{39}$

Vattel's willingness to apply the law of war to civil wars marks a notable development in thinking with regard to NIAC: from the complete exclusion of law to the recognition that at least some forms of internal wars should be governed by law. This development, as we shall see below, became part of international law from the nineteenth century through the adoption of CA3 of the 1949 Geneva Conventions.

\subsubsection{0s-1949}

The clear distinction between international wars and internal conflicts continued to be applied during the period from the 1800s to 1949 . International wars were regulated under international law and internal wars, in general, were not. The application of international law to internal wars, in practice, only happened in those limited situations where states recognised the rebels as belligerents (the so-called doctrine of belligerency). The legal justification for the distinction between international wars and internal wars was based on the principle of sovereignty. Behind the legal justification, however, stood a practical (and indeed much simpler) reason: states did not want to recognise non-state groups as equal to them and thus grant those groups belligerency rights. Nevertheless, the idea that states need to apply humanitarian norms to internal wars, without recognising the status of the non-state group, had continued to develop.

Until the adoption of the 1949 Geneva Conventions, then, internal wars were classified into three groups: (a) rebellion; (b) insurgency; (c) belligerency. The first two groups were not considered to be regulated under international law. Group (c), however, was considered to be regulated under the same law that applied between states.

Put simply, rebellion was defined as a short or sporadic insurrection against the authority of the state. ${ }^{40}$ The rules of international law did not regulate the conduct of hostilities in rebellion. ${ }^{41}$ As the International Criminal Tribunal for the former Yugoslavia (ICTY) elaborated, states

\footnotetext{
38 Ibid., [290]-[291].

39 Moreover, Vattel argued that the sovereign was required to grant clemency when the rebels were numerous. Ibid., [290]-[291]; see also Perna (2006),

40 Falk (1964), 199; see also, Wilson (1988), 23.

41 Roth (1999), 173.
} 20-21. 
considered rebellions as an internal matter 'coming within the purview of national criminal law'. ${ }^{42}$ It was prohibited for third states to provide assistance to the rebels. ${ }^{43}$ Such assistance could be considered a violation of the principle of non-interference in internal matters of the state. ${ }^{44}$ In contrast to rebellion, insurgency was defined by the presence of continuing insurrections and extended violence in which the outcome of the conflict was in doubt. ${ }^{45}$ Insurgency was recognition of a factual situation and did not entail any automatic application of rights under international law, but rather such application only to the extent conceded by the de jure authority. ${ }^{46}$ As explained below, both territorial states and third states could recognise specific hostilities as insurgency.

The common denominator of rebellion and insurgency was that they were both considered internal threats to states' sovereignty that the de jure government of the territorial state had authority to quell. The main rationale behind differentiating between rebellion and insurgency was based both on practical self-interest of states and on humanitarian interest. ${ }^{47}$ Lauterpacht states that the reasons of recognition were 'convenience, of humanity, or of economic interest'. ${ }^{48}$ In recognising a state of insurgency, states maintained their control with regard to which norms would apply. As states were reluctant to grant any rights or legitimacy to non-state groups, recognition of insurgency allowed states to apply humanitarian norms without granting belligerency rights to the non-state group members.

Third states were also entitled to recognise situations of insurgency. Such recognition allowed third states to formulate relations with the insurgents, without violating the existing prohibitions on assisting rebels on the one hand, and, on the other hand, without invoking the relevant rules of belligerency, which would have required them either to maintain neutrality or to formally support the non-state group and thus involve declaring war on the territorial state. ${ }^{49}$ As was stated by Falk:

\footnotetext{
42 Prosecutor v. Tadić (Jurisdiction Appeal) IT-94-1-AR72 (2 October 1995),

Lauterpacht (1947), 230; Falk (1964), 197.

Kotzsch (1956), 231.

Castrén (1966), 24 and 28.

Cullen (2010), 13; Lauterpacht (1947), 277; Castrén (1966), 207-223.

47 However, see Sivakumaran (2012), 14-15 (arguing that 'it was the need to clarify the legal relationship and not a desire for humanitarian protection that brought about recognition of belligerency').

48 Lauterpacht (1947), 277.

49 Cullen (2010), 12; Neff (2005), 269; Falk (1964), 200.
} [96]. 
[i]n general, the status of insurgency is a flexible instrument for the formulation of claims and tolerances by third states. If it is used to protect economic and private interests of nationals and to acknowledge political facts arising from partial successes by insurgents in an internal war, then it can adjust relative rights and duties without amounting to a mode of illegal intervention in internal affairs. ${ }^{50}$

In the case of belligerency, the conflict between the territorial state and the non-state group was equivalent to a war between states, in which both sides to the conflict would be bound to comply with humanitarian norms. In such cases (very much the minority of all civil wars), the distinction between internal wars and international wars would be supplanted and the internal war would be regulated according to the law that applies between states. ${ }^{51}$ Recognition of belligerency by the territorial state could be either de jure or de facto by treating the insurgents as belligerents (e.g. by granting them belligerency rights or prisoner-of-war (POW) status). ${ }^{52}$ A third state could recognise belligerency 'by a formal announcement of some kind, or implicitly by way of "a series of acts which leaves no doubt as to [the] intention" of the recognising state'. ${ }^{53}$ Recognition of belligerency by a third state entailed the application of customary rules of neutrality between the third state and the parties to the conflict. ${ }^{54}$ Although recognition by the third state did not change the legal rights between the territorial state and the non-state group, ${ }^{55}$ widespread

50 Falk (1964), 202.

51 Stone (1959), 305; Oppenheim (1952), 211-212.

52 Cullen (2010), 16.

53 Neff (2005), 266-268 (citing the 1900 resolution of the Institute of International Law). See also Cullen (2010), 16-17.

54 Brierly and Waldock (1963), 141. Additional normative ramifications that stem from the recognition of belligerency were explained by the US Supreme Court in the case of US v. The Three Friends 166 US 1 (1897), 63 ('recognition of belligerency involves the rights of blockade, visitation, search and seizure of contraband articles on the High Seas, and abandonment of claims for reparation on account of damages suffered by our citizens from the prevalence of warfare').

55 Case concerning certain German interests in Polish Upper Silesia (Germany v Poland) (Merits) [1926] PCIJ Report Series A No 7, 28 (ruling that the recognition conferred on the National Polish Army (a non-state group), who fought against Russia, by the Allied Powers in World War I had no ramifications as far as Germany was concerned); see also AP Commentary, 1321; Moir (2002), 8; Sivakumaran (2012), 15. But see Cullen (2010), 20 ('[b]y recognising the belligerency of parties to an internal conflict, neutral states also obligated the application of humanitarian norms by both insurgents and the armed forces of the de jure government'). It could also be argued that while recognition by third 
recognition of third states could induce the territorial state to grant recognition. ${ }^{56}$

On the basis of traditional statements from this period, such as an 1867 opinion of the British Law Officers, ${ }^{57}$ as well as the writings of Oppenheim and Lauterpacht, Sivakumaran has summarised neatly the following criteria arguably required for the recognition of belligerency:

(1) a civil war 'accompanied by a state of general hostilities'; (2) 'occupation and a measure of orderly administration of a substantial party of national territory by the insurgents'; (3) observance of the laws and customs of war by the purported belligerent group 'acting under a responsible authority' and, rather more controversially, (4) 'the practical necessity for third States to define their attitude to the civil war'. ${ }^{58}$

The question whether the recognition of the non-state group as belligerents was mandatory and if so under what conditions, remained contro-

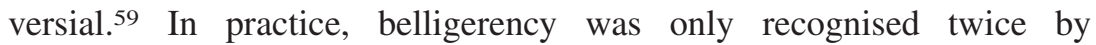

states does not change the legal rights between the territorial state and the non-state group, in situations in which the non-state group is organised and represents a large number of civilians the territorial state would have to acknowledge the belligerent rights of the non-state group). See also Oppenheim (1952), 209 and especially 251-253.

56 Greenspan (1959), 19; Zorgbibe (1977), 112-113.

57 Opinion of the Law Officers (J. B. Karslake, C. J. Selwyn, and R. Phillimore), 14 August 1867, reproduced in McNair (1956), Volume One: Peace, 143, 144 ("whether the Insurrection has or has not assumed the dimensions of War, and whether the legitimate interests of the neutral state do or do not require that she should claim from both parties the performance towards her of the obligations incident to the Status of a belligerent.. the length of time during which the contest has existed; the number, order, and discipline of the rebel forces; their subordination to a de facto existing Government, capable of maintaining international relations with foreign states; the acts of the Government against which the rebels are in arms, both with respect to the rebels themselves and to foreign States').

58 Sivakumaran (2012), 11 (quoting Oppenheim (1952), 249-50 and also referring to Lauterpacht (1947), 176).

59 Lauterpacht, for example, argued that once certain conditions have been fulfilled, recognition is only a declaratory act of recognition of facts. See Lauterpacht (1947), 176 and 253-255. For contrary opinions see Falk (1964), 206; Elder (1979), 39. See also Neff (2005), 264 (stating that 'the prevailing view, however, came to be that a set of objective criteria for recognition of belligerency did exist - but with the key proviso that, if they were satisfied, then foreign states were permitted to recognise belligerency, but not compelled to do so'). 
territorial states: in the American Civil War and the Boer War. ${ }^{60}$ Bearing in mind this limited state practice, which mainly highlights the selectivity of the application of belligerency, and that the act of recognition was mainly a political one, the argument that belligerency was mandatory (under specific conditions) is not convincing.

Belligerency, then, unlike insurgency, entailed the full application of international law. The rationale behind the full application of law can be examined from two perspectives: that of the territorial states and that of the third states. From the territorial states' point of view, the full application of law was needed in order to apply humanitarian norms. This was explained by the US Supreme Court when it stated that recognition of belligerency was 'made in the interests of humanity, to prevent the cruelties which would inevitably follow mutual reprisals and retaliations' ${ }^{61}$ The same line of reasoning can be found in the Lieber Code ${ }^{62}$ which stated that 'humanity' was the reason for applying the law to civil wars. ${ }^{63}$ Once again, we can see that the willingness to apply humanitarian norms was the leading incentive behind the doctrine of belligerency and behind the extension of legal norms to NIAC. ${ }^{64}$ Nevertheless, since recognition of belligerency was often considered " a sign of weakness" and likely to enhance the "prestige" of the armed group', 65 it was often granted when the territorial state had also other interests and motives such as the need to protect its interests in territory under the control of the non-state group or to protect its maritime activities. ${ }^{66}$

With regard to third states' interests in the recognition of belligerency, the US Supreme Court has phrased it forthrightly: 'Belligerency is recognized when a political struggle has attained a certain magnitude, and affects the interests of the recognizing power ... it belongs to the political department to determine when belligerency shall be recognized.' ${ }^{67}$ Therefore, as explained by Cullen, decisions to recognise belligerency by a third state had two elements: first, a factual appraisal of

60 Neff (2005), 258-264.

61 US Supreme Court, Williams v. Bruffy, 96 US 176 (1877), 187.

62 Instructions for the Government of Armies of the United States in the Field, prepared by Francis Lieber, promulgated as General Orders No. 100 by President Lincoln, 24 April 1863 (reproduced in Schindler and Toman (eds.) (1988), 3).

63 Article 152 of the Lieber Code. See also Wright (1971), 42.

64 See also Perna (2006), 32.

65 Sivakumaran (2012), 16 (quoting Chen (1951), 371).

66 Sivakumaran (2012), 16; G. Abi-Saab (1988), 218.

67 US Supreme Court, US v. The Three Friends 166 US 1 (1897), 63 (emphasis added). 
whether the conflict had reached an intensity which resembles an armed conflict between two states; second, an inherently political judgement, which was contingent on the interests of the third state. ${ }^{68}$ These interests varied from holding the non-state group directly accountable for its conduct, to the desire to impose a legal blockade or declare neutrality. ${ }^{69}$ Other interests could be the desire to trade with both the belligerents and the state and to exempt the recognising state from 'paying custom duties to the state if the duties had already been paid to the belligerents'. ${ }^{70}$ Indeed, the need to regulate the relations between the belligerents and the neutral sides had an important role in the development of the doctrine of belligerency. ${ }^{71}$ On some occasions, albeit more rare, humanitarian concerns motivated the recognition of belligerency by third states. ${ }^{72}$

In the Tadic Jurisdiction Decision, the Tribunal referred to the distinction between insurgency (which entailed only partial application of the law) and belligerency (which entailed full application of the law): "[the] dichotomy was clearly sovereignty-oriented and reflected the traditional configuration of the international community, based on the coexistence of sovereign States more inclined to look after their own interests than community concerns or humanitarian demands'. ${ }^{73}$ This interpretation, while common, does not give an entirely fair account of the whole picture. While it is undisputed that sovereignty-oriented perceptions were a dominant factor behind the distinction between insurgency and belligerency, it is important to understand that the existing law gave limited tools to territorial states that actually wanted to extend humanitarian protection. In this period, states had to choose between full application of the law in the form of belligerency, which would have invoked humanitarian protection but also belligerency rights to the members of the non-state groups, ${ }^{74}$ and flexible application of humanitarian norms

68 Cullen (2010), 17; these two elements are also based on the four traditional conditions for recognition of belligerency; see text to note 58 supra.

69 Legal blockade and neutrality were only possible in armed conflicts between belligerents. For further elaboration on different reasons for states to recognise belligerency, see Moir (2002), 8-11.

70 Sivakumaran (2012), 15 and the sources referred to therein.

71 Neff (2005), 251.

72 Sivakumaran (2012), 15 (referring, as an example, to the British recognition of the Greek forces as belligerents in the Greek war of independence in the 1820s).

73 Prosecutor v. Tadić (Jurisdiction Appeal) IT-94-1-AR72 (2 October 1995), [96].

Opinion of the Law Officers (RT Reid and F Lockwood), 26 April 1895 (reproduced in McNair (1956), Volume Two: Peace, 371); Kelsen (1952), 292; 
through recognition of insurgency, which did not include belligerency rights. Considering that even today states are usually not willing to pay the price of granting POW status to non-state group members, it is understandable that states preferred to abstain from the recognition of belligerency. Moreover, recognition of belligerency entailed the legal right of non-state groups to obtain credit abroad. ${ }^{75}$ Today, on the other hand, even with the extensive application of IHL in NIAC, obtaining credit abroad could invoke state responsibility for the supplying state for unlawful intervention in the territorial state's sovereignty. ${ }^{76}$ Thus, when comparing the price of recognition of belligerency that territorial states had to bear in light of the price that states are willing to pay today for the application of humanitarian law, it is clear that the cost of recognition of belligerency was often too high, as it may be today. Indeed, the high price of recognition may explain the fact that recognition of belligerency by territorial states has become so rare. ${ }^{77}$ This scarcity of practice has led various scholars to conclude that the doctrine of belligerency had fallen into desuetude. ${ }^{78}$ However, besides the fact that recognition of

Castrén (1966), 156; Neff (2005), 263 ('In addition, it should be appreciated that the expression "recognition of belligerency" is actually somewhat misleading, in that it might be misunderstood to constitute merely a recognition of the insurgents as lawful belligerents, with the full rights of war, rather than as mere criminals. Recognition of belligerency did have that effect. But the full significance of it was that it referred to the over-all status of the conflict as such, not merely to the character of the rebel faction alone').

75 Falk (1964), 205; Cullen (2010), 20.

76 Military and Paramilitary Activities in and against Nicaragua (Nicaragua v. US) (Merits) [1986] ICJ Reports 14, [228].

77 UK Ministry of Defence, The Manual of the Law of Armed Conflict (2004), 382 ('The doctrine [of belligerency] has declined to the point where recognition of belligerency is almost unknown today'). See also Detter (1987), 40-43 and Sivakumaran (2012), 17-20 (providing a detailed examination of instances of recognition of belligerency). See also Perna (2006), 30 (stating additional reasons for the scarce recognition of belligerency: (i) territorial states were concerned that recognition would advantage the insurgents; (ii) civil war usually did meet the conditions required for recognition of belligerency; (iii) third states were concerned that recognition would be perceived as a hostile act by the territorial state).

78 See for example, Guilfoyle (2010), 192 (stating that 'it is unclear, even doubtful, that the doctrine survived the nineteenth century') and 216 (stating that 'the doctrine [of belligerency] is widely presumed to have fallen into desuetude'); Sanger (2010), 425 ('It can be stated with a considerable degree of certainty that the doctrine has "fallen into desuetude"); Bartels (2009), 51 (stating that the doctrine of belligerency in the twentieth century 'seemed to have 
belligerency by third states still occasionally occurs, ${ }^{79}$ a territorial state can still decide to treat an internal conflict as if it were an IAC in which all the norms of that legal regime apply. ${ }^{80}$

The imperfections of the doctrine of belligerency explain the creation of the law of NIAC, which is not dependent on recognition and is clearer in terms of its scope of application. We can thus understand the creation of the law of NIAC in the context of the ongoing willingness of states to extend humanitarian protection on the one hand, and to deny POW status to non-state group members and prohibit foreign involvement on the other hand. In the next chapter, this understanding will show us that the extension of humanitarian norms via treaty law and customary law to NIAC is compatible with states' opinions from the nineteenth century. As we shall see below, as much as the law has developed, states still, in general, regard non-state group members as criminals and still justify this approach under arguments of state sovereignty and national security.

\subsection{THE DISTINCTION AFTER THE 1949 GENEVA CONVENTIONS}

The Second World War marks a watershed in public international law and IHL in particular. The horrors and the suffering that the war created in general, and the atrocities perpetrated by the Nazi regime in particular, yielded a consensus between states that humanitarian norms should be more securely applied in the conduct of hostilities - both in IAC and in NIAC. ${ }^{81}$ This consensus also stems from the experience of the Spanish

become obsolete'); Moir (2002), 18-21 (discussing the decline in the recognition of belligerency and stating that by the beginning of the twentieth century this doctrine 'was rapidly becoming obsolete'); Oglesby (1971), 110-114 (arguing that the doctrine of belligerency has fallen into 'desuetude'); 'The Public Commission to Examine the Maritime Incident of 31 May 2010' ('the Turkel Commission Report') (2011), 46 (stating the doctrine of belligerency 'has become less important and today is almost irrelevant'); but see Scobbie (2012A) (criticising the use of the term 'desuetude' with regard to customary law and stating that ' $[t]$ he doctrine might be in decline but it is not yet dead').

79 See, for example, the sources cited in Wills (2011), 182, note 26.

80 Dinstein (2009A), 53; Sivakumaran (2012), 20. See also CA3 ('The Parties to the conflict should further endeavour to bring into force, by means of special agreements, all or part of the other provisions of the present Convention').

81 For a description of the importance of these events for the development of IHL see Ratner and Abrams (2001), 5-14. 
Civil War, which broke out in 1936, and the failure of international law to regulate it. ${ }^{82}$ The next sections examine notable stages where the distinction between IAC and NIAC has been addressed and assessed directly by states.

\subsubsection{Common Article 3 of the 1949 Geneva Conventions}

The drafting of CA3 marks the starting point of the positive body of law of NIAC. The Article embodies the realisation of the willingness of states to extend humanitarian norms to NIAC without granting POW status to members of non-state groups. As we will see, in line with the development examined in the period from the 1800s to 1949, from the earlier attempts to regulate NIAC through the preparatory work to the drafting of $\mathrm{CA} 3$, the willingness of the majority of states to extend humanitarian norms to NIAC without granting POW status to members of non-state groups stayed consistent. The position that states took with regard to non-state groups was mainly based on the principle of state sovereignty and the perception that non-state groups do not have belligerency rights.

\subsubsection{The road to Common Article 3}

As noted by Elder, the history of CA3 is tortuous. ${ }^{83}$ As early as 1912, at the Ninth International Conference of the Red Cross, the International Committee of the Red Cross (ICRC) tried to introduce a proposal that would allow National Societies of the Red Cross to offer humanitarian aid for both belligerent sides during civil war and insurrections. ${ }^{84}$ States, however, rejected this initiative. ${ }^{85}$ The Russian delegate articulated the reason for rejecting this initiative quite simply: '... the Red Cross Societies should have no duty towards insurgents or bands of revolutionaries whom the laws of my country regard as criminals' ${ }^{86}$ This perspective towards non-state group members as criminals was neither new nor surprising. Nevertheless, the ICRC continued its endeavour to extend humanitarian relief to NIAC.

\footnotetext{
82 Jinks (2004), 401 and the sources cited therein at note 190.

83 Elder (1979), 41.

84 According to the draft, the National Societies of the Red Cross would be permitted to aid in the care of the sick and wounded non-combatants, see Taubenfeld (1974), 502-503.

85 Moir (2002), 22.

86 Quoted in Schlögel (1970), 125.
} 
In 1921, at the Tenth International Conference of the Red Cross, the ICRC managed to pass a resolution which allowed it to offer humanitarian service to all victims of NIAC and internal disturbances. ${ }^{87}$ It is probable that historical events such as the Russian revolution of 1917 and the Hungarian revolution of 1919 had again demonstrated the necessity of offering humanitarian relief to victims of NIAC and thus helped the ICRC in passing the resolution. ${ }^{88}$

In 1938, two years after the beginning of the Spanish civil war, in which the ICRC had received cooperation from the belligerent sides, ${ }^{89}$ the Sixteenth Conference of the Red Cross was held and the ICRC managed to have passed a resolution that called on the National Societies of the Red Cross to apply all the rules of international law (mainly the Geneva Convention of 1929 and the Hague Convention X [for the Adaptation to Maritime Warfare of the Principles of the Geneva Convention] of 1907) to NIAC. ${ }^{90}$ As much as this resolution was an important step in the process of extending humanitarian relief to internal armed conflicts, ${ }^{91}$ we should not interpret this decision as an indication that in 1938 states were willing not only to extend humanitarian norms to NIAC, but also to apply the rules of IAC in toto. Although governmental representatives participated in the Sixteenth Conference of the Red Cross, the resolution only addressed the National Societies of the Red Cross and had no binding effect on the way that states should conduct their wars with non-state groups. Moreover, the resolution was adopted in the midst of the Spanish civil war, which was highly intense and involved international intervention. ${ }^{92}$ Thus, it was suggested that it is possible that states regarded this decision as applicable only to those types of conflict. ${ }^{93}$

87 See full text of the resolution in ibid., 125-126.

88 See Article 4 of the resolution: '... The Xth International Red Cross Conference recalling the distressing experiences of the Red Cross in countries engaged in civil war ...'. See discussion in Perna (2006), 37 and Schlögel (1970), 125.

89 Schlögel (1970), 126.

90 Resolution quoted in Schlögel (1970), 126-127.

91 See GCI Commentary, 41 (stating that '[The resolution] envisaging, explicitly and for the first time, the application to a civil war, if not of all the provisions of the Geneva Conventions, at any rate of their essential principles').

92 It should be noted that some scholars actually considered the Spanish civil war as IAC. See, for example, Lauterpacht (1947), 184 (stating that the Spanish civil war 'has acquired the characteristics and significance of an international contest').

93 Perna (2006), 38. 
In 1946, when the bloody memories of the Second World War were still fresh, the ICRC was working on revising the laws of armed conflict. ${ }^{94}$ At the Preliminary Conference of the National Red Cross Societies, the ICRC proposed that states be invited to expressly declare their willingness, on the basis of reciprocity, to apply the rules of IAC to NIAC. ${ }^{95}$ This modest proposition was based on the ICRC's understanding that it should not propose innovations that were unlikely to be accepted by states. ${ }^{96}$ Nevertheless, the Preliminary Conference proposed to insert at the beginning of the Geneva Convention a far more ambitious Article, according to which:

[i]n the case of armed conflict within the borders of a State, the Convention shall also be applied by each of the adverse Parties, unless one of them announces expressly its intention to the contrary. ${ }^{97}$

This proposal was, and might even be considered today, groundbreaking, as it suggested that the rules of IAC would apply to NIAC in toto. This would mean that non-state groups would be entitled to POW status - a proposition that is unlikely to be accepted even today. The proposal also obliterated the traditional distinction between different internal armed conflicts, and presented a new concept: 'armed conflict', which did not elaborate any minimum requirement for intensity. Nevertheless, the proposal still emphasised that the application of law was contingent on the willingness of states to apply the law.

Following the 1946 Preliminary Conference, the 1947 Conference of Government Experts proposed the following draft Article for the Geneva Conventions:

In case of civil war, in any part of the home or colonial territory of a Contracting Party, the principles of the Convention shall be equally applied by the said Party, subject to the adverse Party also conforming thereto. ${ }^{98}$

This draft seemed more congruent with states' desires and more reasonable than the 1946 draft: ${ }^{99}$ first, it did not require the full application of

\footnotetext{
$94 \quad$ Schlögel (1970), 127.

95 GCI Commentary, 41.

96 Perna (2006), 50-51.

97 GCI Commentary, 41-42.

98 Schlögel (1970), 128.

99 As was noted by Ash, contrasting the 1946 Preliminary Conference and the 1947 Conference of Government Experts demonstrates 'the divergent interests of the ICRC and National Red Cross Societies, as humanitarian advocates of
} 
law but only its principles. Hence, it could be interpreted as a proposal that does not entail the application of POW status to NIAC and the legitimisation of non-state groups; second, the emphasis was on the reciprocal behaviour of the two sides and not on their precise announcements.

Encouraged by the fact that the Conference of Government Experts did not reject the basic idea of regulating NIAC, the ICRC proposed the following draft at the 1948 International Conference in Stockholm:

In all cases of armed conflict which are not of an international character, especially cases of civil war, colonial conflicts, or wars of religion, which may occur in the territory of one or more of the High Contracting Parties, the implementing of the principles of the present Convention shall be obligatory on each of the adversaries. The application of the Convention in these circumstances shall in nowise depend on the legal status of the parties to the conflict and shall have no effect on that status. ${ }^{100}$

The 1948 proposal incorporated two important modifications derived from the 1947 proposal: first, the rules of IAC were not to apply in toto but only as principles; second, the legal status of the parties to the conflict was to remain the same. Thus, we can understand that under this proposal, non-state group members would not be entitled to POW status. Although this proposal reflected more accurately the above-detailed states' opinions with regard to the law that should apply in NIAC than the 1946 proposal, during the Conference, the proposal profoundly changed into what is known as the 'Stockholm Proposal':101

In all cases of armed conflict not of an international character which may occur in the territory of one or more of the High Contracting Parties, each of the Parties to the conflict shall be bound to implement the provisions of the present Convention, subject to the adverse Party likewise acting in adherence thereto. The Convention shall be applicable in those circumstances, whatever the legal status of the Parties to the conflict and without prejudice thereto. ${ }^{102}$

There are a number of important differences between the 'Stockholm Proposal' and the original ICRC proposal of 1948. First, the phrase 'especially cases of civil war, colonial conflicts, or wars of religion' was deleted. Second, a provision on reciprocity was added (only to the draft

individual rights and protections on the one hand, and States Parties, as protectors of sovereign rights on the other', see Ash (2007), 280.

100 GCI Commentary, 42-43.

101 Elder (1979), 43.

102 Citied in Moir (2002), 23-24 (emphasis added). 
of the Third and the Fourth Conventions). ${ }^{103}$ This change could be understood as meant to diffuse the foreseeable objections of states that the Convention would put an unfair burden on them in relation to non-state groups. Third, the term 'provisions' replaced the term 'principles'. This basically meant that all provisions of the law of IAC would apply in toto to NIAC (exactly as was proposed in 1946). ${ }^{104}$ Therefore, according to the proposal, NIAC (which so far had not been regulated under international law) would be regulated as IAC and the distinction between the two types of armed conflicts would be eliminated. This change would still be considered radical even today, and caused heated discussions in the 1949 Diplomatic Conference between the different states.

\subsubsection{The Diplomatic Conference (1949) and the 'Stockholm Proposal'}

At the Diplomatic Conference in Geneva in 1949, four primary committees were established in order to discuss different topics related to the draft Conventions. The 'Joint Committee' was in charge of the topic of 'provisions common to all four Conventions', 105 and therefore dealt with what was to become CA3. ${ }^{106}$ Examination of the discussions regarding CA3 shows that regulating NIAC was one of the most controversial issues, ${ }^{107}$ and this can help us understand how states regarded the distinction between IAC and NIAC.

The basic text for the discussions of the Joint Committee with regard to CA3 was the 'Stockholm Proposal'. ${ }^{108}$ From the beginning, a large

\footnotetext{
103 GCIII Commentary, 31; Elder (1979), 43.

104 It is interesting to note that the ICRC commentaries failed to mention this third change. See GCIII Commentary, 31. The change was noted by Elder (1979), 43.

105 All the participant states at the Diplomatic Conference were represented in the Joint Committee.

106 GCIII Commentary, 7; see also Final Record, vol. II-A, Minutes of the 4th Plenary Meetings (25 April 1949), 71-74; It should be noted that CA3 changed numbers during the course of the 1949 Diplomatic Conference at Geneva. At the beginning the Article was the fourth paragraph of Article 2 and later was separated from Article 2 to become Article 2A. For convenience, the Article will be referred to as Common Article 3 (CA3) throughout this chapter.

107 According to the Soviet delegation '[n]o other issue has given rise to such a long discussion and to such a detailed and exhaustive study as the question of the extension of the Convention[s] to war victims of conflicts not of an international character'. See Final Record, vol. II-B, Minutes of the 18th Plenary Meeting (28 July 1949), 325; see also GCI Commentary, 43.

108 GCIII Commentary, 31.
} 
number of delegates opposed the idea that the law of IAC should apply in toto to NIAC. ${ }^{109}$ The reasons behind this objection were summarised in the ICRC Commentary:

It was said that it [the Article] would cover all forms of insurrections, rebellion, and the break-up of States, and even plain brigandage. Attempts to protect individuals might well prove to be at the expense of the equally legitimate protection of the State. To compel the Government of a State in the throes of internal conflict to apply to such a conflict the whole of the provisions of a Convention expressly concluded to cover the case of war would mean giving its enemies, who might be no more than a handful of rebels or common brigands, the status of belligerents, and possibly even a certain degree of legal recognition. There was also a risk of ordinary criminals being encouraged to give themselves a semblance of organization as a pretext for claiming the benefit of the Convention, representing their crimes as 'acts of war' in order to escape punishment for them ... Moreover, it was asked, would not the de jure Government be compelled to release captured rebels as soon as order was re-established, since the application of the Convention would place them on the same footing as prisoners of war? Any such proposals giving insurgents a legal status, and consequently support, would hamper the Government in its measures of legitimate repression. ${ }^{110}$

As we can see, the reasons behind the objection to applying the law of IAC to NIAC in toto were all based on a common thread: states were not willing to legitimise or to grant POW (or belligerent) status to non-state group members. ${ }^{111}$ Accordingly, states wanted to keep their right to prosecute non-state group members under criminal law. ${ }^{112}$ This common thread highlights another important point: the states that objected to the

109 GCIII Commentary, 32; Elder (1979), 43; for in-depth examination of the discussions in the Joint Committee, see Cullen (2010), 29-36.

110 GCIII Commentary, 32.

111 Nevertheless, behind this common thread were different nuances and emphases. Some states, like the US for example, emphasised the right of the state to prosecute non-state members. Other states, like Canada, also emphasised the right to quell a rebellion (see Final Record, vol. II-B, Summary Records, Joint Committee, 2nd Meeting, 13). The UK not only raised concerns regarding legitimising non-state groups ('the application of the Conventions would appear to give the status of belligerents to insurgents, whose right to wage war could not be recognized'), but also stated that the application of the Convention would 'strike at the root of national sovereignty and endanger national security' (see Final Record, vol. II-B, Summary Records, Joint Committee, 1st Meeting, 10).

112 As was stated by the American delegate, '[e]very government had a right to put down rebellion within its borders and to punish the insurgents in accordance with its penal laws' (Final Record, vol. II-B, Summary Records, Joint Committee, 2nd Meeting, 12). 
proposal did not raise any objection to the principle that humanitarian relief should be extended to victims of war. Thus, in correlation to the above historical analysis of the nineteenth century, the main reason behind the distinction between IAC and NIAC was the status of non-state group members and the right of states to quell rebellions.

The arguments in favour of the 'Stockholm Proposal' were summarised in the ICRC Commentaries as well:

The advocates of the Stockholm draft, on the other hand, regarded the proposed text as an act of courage. Insurgents, said some, are not all brigands. It sometimes happens in a civil war that those who are regarded as rebels are in actual fact patriots struggling for the independence and the dignity of their country. It was argued, moreover, that the behaviour of the insurgents in the field would show whether they were in fact mere felons, or, on the contrary, real combatants who deserved to receive protection under the Conventions, Again, it was pointed out that the inclusion of the reciprocity clause in all four Conventions would be sufficient to allay the apprehensions of the opponents of the Stockholm proposals. It was not possible to talk of 'terrorism', 'anarchy' or 'disorder' in the case of rebels who complied with humanitarian principles. Finally, the adoption of the Stockholm proposals would not in any way prevent a de jure Government from taking measures under its own laws for the repression of acts considered by it to be dangerous to the order and security of the State. ${ }^{113}$

It is important to note that although the 'Stockholm Proposal' would have resulted in the elimination of the distinction between IAC and NIAC, closer examination of the reasons that led states to support the Proposal suggests that at least three out of six states that supported the Proposal still recognised that there was and should be a distinction between the two. ${ }^{114}$ Mexico saw the 'Stockholm Proposal' as courageous and supported it on the basis of humanitarian considerations, ${ }^{115}$ but agreed that modifications might be needed. ${ }^{116}$ Norway, while supporting the Proposal and arguing for the application of humanitarian rules in NIAC, also

\section{GCIII Commentary, 32-33.}

114 At this stage of the discussions, six states supported the 'Stockholm Proposal': Romania, Hungry, Norway, Denmark, the USSR and Mexico.

115 Final Record, vol. II-B, Summary Records, Joint Committee, 1st Meeting, 11 ('In civil wars there might also be movements for emancipation of a morally creditable character. But in any case, the rights of the State should not be placed above all humanitarian considerations').

116 Final Record, vol. II-B, Summary Records, Joint Committee, 1st Meeting, 11 ('The Conference at Stockholm had been courageous in placing this principle at the beginning of the Conventions. It might be advisable, in order to protect the rights of the State, to forgo the eventual recourse to a Protecting Power; but in 
argued that the application of the Convention entailed no consequence with regard to the legal status of opposing parties. ${ }^{117}$ Similarly, the Soviet Union, while supporting the Proposal, emphasised that states could still prosecute non-state group members according to their national law. ${ }^{118}$ Thus, we should not interpret the support of states for the 'Stockholm Proposal' as tantamount to support for obliterating the distinction between IAC and NIAC. At least with regard to some of the states, supporting the 'Stockholm Proposal' was aimed at extending humanitarian norms to internal armed conflicts, while still recognising that there was and should remain a difference between NIAC and IAC.

Faced with a variety of opinions and suggested amendments to the 'Stockholm Proposal', pursuant to the Swiss delegation's proposal, the Conference referred the study of the Article to a sub-committee (the 'Special Committee'). ${ }^{119}$ By the end of the third meeting of the Special Committee, when the debates regarding the 'Stockholm Proposal' continued and various amendments were proposed, ${ }^{120}$ it became clear that states were willing to extend humanitarian norms to NIAC but that there was a real controversy with regard to the 'Stockholm Proposal'. Thus, by request of the chairman (Plinio Bolla of Switzerland), the Special Committee voted, by ten votes to one, with one abstention, in favour of

this case the role of the Protecting Power should devolve on some international body such as the International Red Cross in order to place the question on a humanitarian plan' (emphasis added)).

117 Final Record, vol. II-B, Summary Records, Joint Committee, 1st Meeting, 11 ( $' .$. hoped that the Conference would agree that purely humanitarian rules should be applied in armed conflicts independently of any recognition of belligerency. The last sentence of Article 2 was a sound innovation. If the application of the Convention entailed no consequence as regards the legal status of opposing parties, that meant that the Convention must be applied even where the opposing parties were not recognized as belligerents').

118 Final Record, vol. II-B, Summary Records, Joint Committee, 2nd Meeting, 12 ('Contrary to the fears expressed by the French and Greek Delegates, the text drafted at Stockholm allowed the States the means of repressing crimes jeopardizing the security of the State in accordance with their national law').

119 The proposal was adopted unanimously at the third meeting (Final Record, vol. II-B, Summary Records, Joint Committee, 3rd Meeting, 16); The Special Committee consisted of Australia, Burma, France, Greece, Italy, Monaco, Norway, the Soviet Union, Switzerland, the United Kingdom, the United States of America and Uruguay (see Final Record, vol. II-B, Summary Records, Joint Committee, 7th Meeting, 26).

120 For in-depth analysis of the discussions and the proposed amendments, see Elder (1979), 44-46 and Cullen (2010), 36-42. 
the principle of extension of the Convention to NIAC. ${ }^{121}$ Accordingly, at the beginning of the fourth meeting, as it became clear that the 'Stockholm Proposal' did not have sufficient support, the Special Committee voted and decided to abandon the Proposal by ten votes for, one against, and one abstention. ${ }^{122}$ These votes are important as they demonstrate once again the willingness of states to extend humanitarian norms to NIAC without obliterating the distinction between NIAC and IAC.

After the two votes, the Special Committee realised that in order to deal with the wishes of states, it could either limit the application of the Convention to specific types of NIAC or limit the norms that would apply in NIAC. ${ }^{23}$ During the weeks that followed, the Special Committee formed small Working Parties that worked on drafting new proposals in light of the understanding of the Special Committee. Three proposals were made by three Working Parties but none received the support of the Special Committee, so it was decided to submit the three proposals to the Joint Committee. ${ }^{124}$ The Joint Committee decided to adopt the proposal of the second Working Party, ${ }^{125}$ consisting of the exact wording of the present CA3, and submitted the proposal to the Plenary Assembly, where the Proposal was finally adopted. ${ }^{126}$

The debates in the Plenary Assembly merit special attention as they give us another glimpse into states' opinions regarding the distinction between IAC and NIAC. ${ }^{127}$ Two distinctly opposed opinions were presented: the Asian bloc on the one hand, represented by Burma, was against the inclusion of any provision pertaining to NIAC; the Soviet bloc on the other hand, represented by the USSR, argued that the suggested

121 Final Record, vol. II-B, the Special Committee of the Joint Committee, 3rd Meeting, 45.

122 Final Record, vol. II-B, the Special Committee of the Joint Committee, 4th Meeting, 45.

123 Final Record, vol. II-B, Seventh Report drawn up by the Special Committee of the Joint Committee, 122.

124 Final Record, vol. II-B, Summary Records, Joint Committee, 11th Meeting, 34-35. For in-depth discussion of the three proposals, see Elder (1979), 46-50.

125 Final Record, vol. II-B, Summary Records, Joint Committee, 11th Meeting, 35 .

126 Of the 47 delegates in attendance, 34 delegates voted in favour, 12 against and 1 abstained (Final Record, vol. II-B, Summary Records, Nineteenth Plenary Meeting, 339).

127 For an analysis of the debates from a different angle, see Cullen (2010), 44-48. 
provision was not broad enough. Between these two opposed approaches, states articulated different concerns regarding the proposed provision.

The arguments raised by Burma can be summarised as follows: first, the provision would apply in situations of disorder and anarchy and thus would weaken the state. ${ }^{128}$ This argument highlights a point worth emphasising: states were not willing to apply CA3 to internal disturbances. However, as other states had tried to explain during the Conference, Burma's objection was not convincing, since it was clear that the provision was not intended to apply to situations of internal disturbances and anarchy. ${ }^{129}$ Second, even if the provision did only apply to rebellions and civil wars, it would serve 'paid mercenaries and quislings acting for their own gain and at the expense of the civilians on behalf of foreign ideologies', ${ }^{130}$ and would help 'those who desire loot, pillage, political power by undemocratic means, or those foreign ideologies seeking their own advancement by inciting the population of another country'. ${ }^{131}$ The third objection, which was similar to the second one, was that the provision would encourage insurgencies. ${ }^{132}$ These objections are also not convincing in hindsight: first, non-consensual foreign interventions remained illegal under international law and the Article did not alter that; ${ }^{133}$ second, the Article did not change the legal status of insurgents. ${ }^{134}$ However, the fear of foreign ideologies and the encouragement of insurgents will echo at a later stage, as the ramifications of internationalisation of NIAC will be discussed. ${ }^{135}$ Finally, it is important to

128 Final Record, vol. II-B, Summary Records, Eighteenth Plenary Meeting, 328.

129 As has already been noted by the Swiss delegation, see Final Record, vol. II-B, Summary Records, Nineteenth Plenary Meeting, 335.

130 Final Record, vol. II-B, Summary Records, Eighteenth Plenary Meeting, 329.

131 Ibid.

132 Ibid., 330. It is interesting to note that Burma's fear of foreign ideologies and rebellions became a self-fulfilling prophecy when the democratic government was brought down by a military coup d'état led by General Ne Win who formed a military socialist dictatorship in 1962. For discussion on the coup d'état and the military dictatorship, see in general Fink (2001).

133 Article 2(7) of the UN Charter; Military and Paramilitary Activities in and against Nicaragua (Nicaragua v. US) (Merits) [1986] ICJ Reports 14, [202]-[209].

134 CA3 clearly states that 'the application of the preceding provisions shall not affect the legal status of the Parties to the conflict'. For the ramifications of the distinction between IAC and NIAC, see Chapter 2.

135 See Chapter 4, Section 4.3. 
note that Burma insisted that its objection to the Article was based only on the arguments stated above, and that the humanitarian norms of the proposal should be applied anyway by each government as 'no Government of an independent country can, or will ever, be inhuman or cruel in its actions towards its own nationals'. ${ }^{136}$ In light of the horrors that were committed during the Second World War, this statement can only be understood as either terribly naïve or insincere.

The USSR on the other hand, following the same line of reasoning that was presented in the Joint Committee meetings, argued for the inclusion of more humanitarian norms:

... why, in the case of conflicts of a non-international character, it would be impossible to apply the provisions of the Wounded and Sick Convention or those of the Civilians Convention, which stipulate, for instance, that civilian hospitals may in no circumstances be attacked, and that women and children shall at all times enjoy particular respect and protection, that, in order to bring relief to the civilian population, the unrestricted transport and distribution of various shipments, such as medicines and medical equipment, shall be guaranteed ... There can be no question but that all these humanitarian provisions must be implemented in all cases of armed conflict, whatever their character may be. ${ }^{137}$

The USSR's proposal to extend the humanitarian scope of the Article was rejected and the proposal submitted by the Joint Committee was approved. ${ }^{138}$ As noted by the Swiss delegate, CA3 constituted a compromise between humanitarian idealism and the rights of realism. ${ }^{139}$ The ICRC, although preferring a wider application of humanitarian norms to NIAC, realised that a compromise was needed and gave its full support to CA3. ${ }^{140}$ The adoption of CA3 symbolised the birth of the distinct body of international law of NIAC. This distinct body of law manifested the broad willingness of states to apply humanitarian norms in NIAC without applying the law of IAC in toto and granting POW status to insurgents. ${ }^{141}$

136 Final Record, vol. II-B, Summary Records, Eighteenth Plenary Meeting, 329.

137 Final Record, vol. II-B, Summary Records, Eighteenth Plenary Meeting, 326.

138 Final Record, vol. II-B, Summary Records, Nineteenth Plenary Meeting, 338-339; see also supra note 126.

139 Final Record, vol. II-B, Summary Records, Nineteenth Plenary Meeting, 336.

140 Final Record, vol. II-B, Summary Records, Nineteenth Plenary Meeting, $336-337$.

141 See AP Commentary, 46; see also Fleck (2008), 612. 
As we shall see below, the distinction between IAC and NIAC has continued to be an important issue for states.

\subsubsection{Attempts of the ICRC to Internationalise NIAC Prior to the Draft of the 1977 Additional Protocols}

At the beginning of the 1970s, in the run-up to the Diplomatic Conference on the Reaffirmation and Development of International Humanitarian Law Applicable in Armed Conflicts (1974-1977) in which the 1977 Additional Protocols were discussed and drafted, ${ }^{142}$ the ICRC suggested that the law of IAC should apply to NIAC in toto in cases where foreign states intervene with their armed forces in NIAC. The first attempt was at the Conference of Government Experts for the Reaffirmation and Development of International Humanitarian Law in Geneva in 1971 when the ICRC proposed the following provision:

When, in case of non-international armed conflict, one or the other party, or both, benefits from the assistance of operational armed forces afforded by a third state, the parties to the conflict shall apply the whole of the international humanitarian law applicable in international armed conflicts. ${ }^{143}$

The motive behind this proposal, as explained by the ICRC, was the desire to extend IHL in order to enhance the protection to war victims as 'outside interventions by foreign states increased the scale of hostilities and the number of victims'. ${ }^{144}$ However, the proposal was objected to by many states' experts who argued as follows:

If the ICRC proposal were adopted, then as soon as a foreign State sent its troops over the border to help the rebels, thereby trespassing to begin with on the territorial rights of the neighbouring State, the State which suffered such aggression would have to treat its own rebels as prisoners of war and its local population as that of an occupied territory. Consequently all that would be needed to legitimize the activities of the rebels and to qualify them as prisoners of war, should they be taken, would be a perfect synchronization of the activities of the foreign State with those of the rebel movement or even simply the despatch of a small detachment of its troops over the border. No

142 The Conference was held in Geneva on the following dates: 20 February-29 March 1974; 3-18 February 1975; 21 April-11 June 1976; and 17 March-10 June 1977.

143 ICRC, Report on the Work of the Conference of Government Experts on the Reaffirmation and Development of International Humanitarian Law Applicable in Armed Conflicts (1971), [290].

144 Ibid., [290]. See also ibid., [291]. 
government could accept that. Furthermore, it would put a premium on foreign intervention on the side of rebels. Consequently, regardless of whether a foreign State intervened or not, the relations between the rebels and the legitimate government would have to continue to be subject to Article 3, while Article 2 would of course apply to relations between government forces and those of the foreign State. ${ }^{145}$

With regard to the hypothesis that the conflict should be internationalised when the territorial state invites the foreign state to intervene, the experts have argued that '[it] would leave the government stranded between the devil and the deep blue sea - [the territorial state] would have either to fight without outside help or to accept the price of such help, namely it would have to grant immunity to those who had risen up in arms against it'. ${ }^{146}$

These arguments highlight again the simple fact; from the states' perspective, the main crux behind the distinction between IAC and NIAC was POW status (which was only granted to combatants of states and not to non-state groups) and the respect for state sovereignty. Therefore, as we examine various doctrines in the next chapters, we should bear in mind that it is reasonable to assume that territorial states would be reluctant to support any legal doctrine which would undermine their right to prosecute non-state entities or their members who fought against them.

At the second session of the Conference of Government Experts in 1972, the ICRC tried to propose an amended draft, according to which NIAC would become IAC only in cases where the territorial state or the territorial state and the non-state groups received military assistance from a foreign state but not in cases where the non-state group received help alone from a foreign state. ${ }^{147}$ However, even this proposal was rejected by the states' experts. ${ }^{148}$ Thus, the issue of military intervention by foreign states in NIAC became a non-issue in the diplomatic conference that led to the adoption of the Protocols. ${ }^{149}$

\footnotetext{
145 Ibid., [301]. See also ibid., [291]-[292].

146 Ibid., [301].

147 ICRC, Report on the Work of the Conference of Government Experts on the Reaffirmation and Development of International Humanitarian Law Applicable in Armed Conflicts (1972), vol. I, [2.332] (draft Article 35(2)).

148 Ibid., [2.352]. The reasons behind the rejection of the proposal by the experts were similar to the reasons that led them to reject the first proposal of the ICRC in the first session of the conference in 1971, as described above. For the summary of objections of the government experts to the ICRC proposal, see ibid., [2.342]-[2.347].

149 Gasser (1983), 146-147.
} 


\subsubsection{Additional Protocols}

1977 was another important year in the life of IHL: driven by the experiences of armed conflicts after the Second World War, ${ }^{150}$ the adoption of the two Additional Protocols of the Geneva Conventions revised and extended the 1949 Geneva law. ${ }^{151}$ In the context of this chapter, the Protocols had two important ramifications with regard to NIAC treaty law: first, Article 1(4) of Additional Protocol I (API) established that wars of national liberation and against racist regimes should be treated as IAC; ${ }^{152}$ second, APII created a set of norms that apply only to NIAC with high intensity and where the non-state group actor is organised and controls a territory. ${ }^{153}$ Through the analysis of the travaux préparatoires of the Protocols we can shed another light on the distinction between IAC and NIAC as it was perceived by states and legal scholars.

\subsubsection{The status of non-state groups at the Diplomatic Conference on the Reaffirmation and Development of International Humanitarian Law Applicable in Armed Conflicts} (1974-1977)

The question whether to allow and invite national liberation movements to participate in the proceedings of the Conference was dealt with in the first session of the Conference (20 February-29 March). ${ }^{154}$ The deliberations on that question provide another glimpse into states' opinions regarding non-state groups. ${ }^{155}$ The foremost palpable point is that states that supported the invitation of non-state groups focused only on national liberation movements which, conveniently enough, did not operate in their territory or against them. ${ }^{156}$ On the other hand, the core of states' objections to the invitation of national liberation movements stemmed

150 See the statement of the ICRC in the Official Records (1974-1977), vol. viii CDDH/I/SR.22, 201.

151 API; APII.

152 Article 1(4) of API.

153 Article 1(1) of API.

154 For in-depth scrutiny of these discussions, see Cullen (2010), 66-69.

155 Although the deliberations were focused specifically on national liberation movements, as explained below, the core of states' objections to the participation of national liberation movements in the Conference stemmed from their specific status as non-state groups.

156 This support could be understood in light of the Cold War and the anti-colonial struggle which were in the background of the Conference, see Perna (2006), 100. 
from their status as non-state groups. Thus, for the sake of understanding states' opinions with regard to non-state groups in general, it is useful to focus only on the objections of states.

Three different arguments were raised against the participation of national liberation movements: first, as non-state groups, they lacked locus standi and therefore could not participate in a diplomatic conference which aimed to codify IHL; ${ }^{157}$ second, some non-state groups were involved in terror against civilians and therefore could not attend an IHL conference; 158 third, the Geneva Conventions and the draft Protocols were not intended to confer legitimacy upon non-state groups and therefore these groups should not be invited. ${ }^{159}$ These objections continued the same line of thought that was described above: according to the states' perspective, non-state groups did not have belligerency rights and international law should not grant any legitimacy to non-state groups.

Despite these objections, there was a clear majority of states favouring inviting the national liberation movements. Though these movements did not have voting rights, ${ }^{160}$ they were put in a strong position to lobby for classifying wars of national liberation as IAC. ${ }^{161}$

157 This was the opinion stated by the Portuguese delegation, Official Records (1974-1977), vol. v, CDDH/SR.6, 61. This opinion was shared by Israel (ibid., 57-58), and by the UK, which 'considered it inappropriate that, at a Conference of sovereign States, entities which were not sovereign States should have the right to participate in any capacity other than that of observers' (ibid., vol. v, CDDH/SR.7, 67).

158 This was stated by the Israeli delegation with regard to the Palestinian Liberation Organization (Official Records (1974-1977), vol. v, CDDH/SR.6, 57-58); See also the position of South Africa (ibid., vol. v, CDDH/SR.7, 67).

159 This was stated by Israel with regard to the Palestinian Liberation Organization: 'The Geneva Conventions of 1949 and the draft Protocols were not a licence to murder, to sabotage, to hijack or to subvert constituted authority: they were not a device for the attainment of political advantage, or recognition, or legitimacy' (Official Records (1974-1977), vol. v, CDDH/SR.6, 57-58) (emphasis added).

160 For the text of the resolution, see Official Records (1974-1977), vol. i, $\mathrm{CDDH} / 55,5$. The national liberation movements permitted to participate in the Conference were: the Republic of Guinea-Bissau; the African National Congress; the Angola National Liberation Front; the Mozambique Liberation Front; the Palestine Liberation Organization; the Pan Africanist Congress; the People's Movement for the Liberation of Angola; the Seychelles People's United Party; the South West Africa People's Organisation; the Zimbabwe African National Union; the Zimbabwe African People's Organisation (see Official Records (1974-1977), vol. v, CDDH/ SR.6, 53 and vol. ii, CDDH/51/Rev.1, 671).

161 Cullen (2010), 69. 


\subsubsection{The drafting history of Article 1(4) of API}

As noted above, Article 1(4) of API extended the provisions of the Protocol beyond IAC to include 'armed conflicts in which peoples are fighting against colonial domination and alien occupation and against racist regimes in the exercise of their right of self-determination', thus equating conflicts that were traditionally considered NIAC with IAC. ${ }^{162}$ Most of the debates concerning this proposal were held in the Plenary Meeting and in Committee I during the first session of the Diplomatic Conference. As been noted by several scholars, Article 1(4) was mainly aimed at South Africa, Rhodesia (as it was then called), Portugal and Israel. ${ }^{163}$ Thus, it appears that this provision was not intended to apply to regular civil wars or NIAC between territorial states and non-state groups. ${ }^{164}$ Nevertheless, by examining the debates we can perceive additional angles on how states regarded the distinction between IAC and NIAC in general. ${ }^{165}$

The supporters of the notion that wars of national liberation should be treated as IAC argued that these armed conflicts have been recognised as international by the international community through different General Assembly resolutions. For example, the Egyptian delegate argued before Committee I:

... wars of national liberation had formed a very important category of armed struggle in the post-1945 period and a number of them were still continuing. Contemporary international law recognized such wars as international armed conflicts. United Nations General Assembly resolution 3103 (XXVIII) was the latest in a stream of resolutions of important international bodies proclaiming that principle. The General Assembly had, indeed, gone further by recommending sanctions against colonial, alien and racist régimes and the provision of assistance to specific liberation movements, and the Security Council in one case had ordered mandatory sanctions. It would be difficult to explain all such international action if wars of national liberation were to be considered merely as armed conflicts of a non-international character. Existing practice provided abundant proof of the international nature of such conflicts. ${ }^{166}$

162 Moir (2002), 90. For debates regarding the classifications of these conflicts as IAC/NIAC see Cullen (2010), 64-65.

163 Aldrich (1991), 6; Draper (1979B), 46.

164 This is demonstrated also by the terms used in Article 1(4): 'colonial domination', 'alien occupation' and 'racist regimes'.

165 An in-depth review of the arguments regarding the internationalisation of national liberation war is beyond the scope of this work. For such review see Cullen (2010), 69-79.

166 Official Records (1974-1977), vol. viii, CDDH/I/SR.2, 8. 
Though this line of reasoning does not reveal much about how these states regarded the general distinction between IAC and NIAC, the words of the President of the Islamic Republic of Mauritania, Mr Ould Dada, give us a glimpse into the reasons why these states wanted to classify such conflicts as IAC:

... the countries of the Third World were asking very little: only that the Conference should not exclude freedom fighters from protection. Such fighters would never renounce their rights. Representatives at the Conference would be preparing rules to enable the ICRC and the various relief agencies to secure respect for human rights. If, for one reason or another, the Conference did not grant freedom fighters the same protection as the oppressors, it would be making a serious mistake ...167

Combined with the drafting of Articles 43 and 44 of API, which granted POW status to insurgents under more flexible terms than Article 4 of GCIII, 168 it is clear that one of the main reasons that motivated states to classify wars of national liberation as IAC was their desire to grant POW status to insurgents. ${ }^{169}$ Once again, we can see that the core difference, from the states' perspectives, between IAC and NIAC was the legal status of insurgents.

The arguments of states, mainly Western, 170 against Article 1(4) do not reveal much about how they regarded the distinction between IAC and NIAC. The first group of objections was based on arguments that classifying conflicts according to their motives or according to the notion of 'just war' would undermine the principles of equality and nondiscrimination that underpinned the Geneva Conventions. ${ }^{171}$ The second group of objections focused on the vagueness of the Article, which might lead to its misuse by insurgents. ${ }^{172}$ The third objection was based on the

167 Official Records (1974-1977), vol. v, CDDH/SR.1, 13-14.

168 Dinstein (2010B), 51-55.

169 See also the statement of the Philippines delegate who emphasised the need to grant POW status to resistance fighters (Official Records (1974-1977), vol. viii, CDDE/I/SR.5, 41); see also the statements of Mozambique (ibid., vol. vi, CDDH/SR.36, 49-50), the Syrian Arab Republic (ibid., vol. vi, CDDH/SR.36, 51) and Poland (ibid., vol. vi, CDDH/SR.36, 52).

170 See Lysaght (1979), 349-356.

171 See, e.g., the Objections of the UK delegate (Official Records (19741977), vol. v, CDDH/SR.13, 134) and the Swiss delegate (Official Records (1974-1977), vol. v, CDDH/SR.13, 137-138).

172 See, e.g., the statement of the Irish delegation in Official Records (1974-1977), vol. viii, CDDH/I/SR.4, 26 ('The expression "armed struggles waged by peoples in the exercise of their right of self-determination" was too 
argument that IHL should not be interpreted according to UN resolutions. ${ }^{173}$ The fourth objection was based on the argument that attaching the application of the Protocol to the political cause of the insurgents would result in hampering the protection of war victims. ${ }^{174}$

The fifth objection reveals another reason why states thought the distinction between IAC and NIAC to be important: it has been argued that non-state group members as such cannot comply with the law of IAC. For example, the Israeli delegate argued that by applying the law of IAC to non-state groups, the Conference was faced with a Protocol 'which obligated non-State entities but could not be applied by them. For example; there were detailed regulations as to courts, tribunals, legal systems and appeals, but non-State entities by definition did not possess such organs'. ${ }^{175}$ This argument, which was shared by other delegations as well, ${ }^{176}$ was not addressed adequately by states that advocated Article 1(4). ${ }^{177}$ Similarly, the non-state groups (the so-called national liberation

vague to be useful in a legal instrument ... Any separatist movement, any band of armed criminals in a colonial territory might claim to be engaged in an armed struggle in furtherance of their people's right to self-determination'); see also the UK's position in Official Records (1974-1977), vol. viii, CDDH/I/SR.2, 13-14.

173 See, e.g. the statement of the French delegate (Official Records (19741977), vol. viii, CDDH/I/SR.2, 14).

174 The US delegation, Official Records (1974-1977), vol. v, CDDH/SR.11, 110; see also the Israeli position, Official Records (1974-1977), vol. vi, CDDH/SR.36, 42.

175 Official Records (1974-1977), vol. vi, CDDH/SR.36, 42.

176 See, e.g., the statements of the Belgian delegation (Official Records (1974-1977), vol. viii, CDDH/I/SR.2, 11-12; the UK, vol. VIII, CDDH/I/SR.4, 28-29); and the US delegation (ibid., vol. viii, CDDH/I/SR.4, 25).

177 Poland, for example, addressed this argument by stating that '[i]t had been said, very wrongly, that national liberation movements would not be in a position to fulfil the legal obligations arising from the Conventions and the Protocol. The representatives of those movements could provide invaluable information on that subject' (Official Records (1974-1977), vol. viii, CDDH/I/ SR.3, 21); Similarly, Egypt only replied as follows: 'some delegations had said that the national liberation movements would be unable to apply the provisions of the Conventions and the draft Protocol because the conditions of their struggle were different in practice from those of international conflicts. That was a false distinction: the material conditions of national liberation struggles were similar to those of resistance movements against foreign occupation, which were specifically mentioned in the Conventions and were classified as international conflicts, it had not been considered that the special conditions of the struggles of such movements would prevent them from applying the Conventions' (vol. viii CDDH/I/SR.5, 34). 
movements), did not explain how exactly they could comply with the obligations under the law of IAC and only replied by denying the argument and arguing that states also did not comply with the law. ${ }^{178}$

Finally, Article 1(4) was adopted as part of Article 1 of API by Committee I of the Diplomatic Conference. It was approved with 70 delegations voting in favour, ${ }^{179} 21$ against, ${ }^{180}$ and 13

178 See, e.g., the statement of the Palestinian Liberation Organization: ' $[\mathrm{t}] \mathrm{he}$ argument that national liberation movements would be incapable of carrying out certain humanitarian obligations was not borne out by the facts. For instance, in the struggle that the Palestinian people was waging against Israel, such international bodies as the ICRC, Amnesty International and even the Israel League for Civil and Human Rights, had testified that Israel had committed many violations of humanitarian law, whereas the Palestinian resistance had always collaborated with the ICRC, in accordance with the Geneva Conventions, and inter alia, had returned Israeli prisoners of war throughout the ICRC' (Official Records (1974-1977), vol. viii, CDDH/I/SR.5, 33); see also the statement of the Mozambique Liberation Front: '[c]ases were known where States had departed from the established rules far more grossly than the liberation movements. If the rules had to be adapted, that might be due to the special conditions of guerrilla warfare and not to the fact that the parties were or were not States' (ibid., vol. viii, CDDH/I/SR.5, 36); see also the statement of Guinea-Bissau: '[i]t has been alleged that the liberation movements were incapable of assuming the obligations arising from the Geneva Conventions. Yet Portugal, which was deemed capable of assuming such obligations, was daily violating those Conventions by using arms that caused unnecessary suffering to the civilian population, such as napalm, fragmentation bombs and defoliants, whereas the liberation movements had returned Portuguese prisoners and had always treated them well, as the ICRC could testify' (ibid., vol. viii, CDDH/I/SR.5, 39).

179 The following states voted in favour: Albania, Algeria, Arab Republic of Egypt, Argentina, Bangladesh, Bulgaria, Burundi, Byelorussian Soviet Socialist Republic, Cuba, Chad, Czechoslovakia, China, Cyprus, Democratic People's Republic of Korea, Democratic Yemen, El Salvador, Finland, Gabon, German Democratic Republic, Ghana, Guinea-Bissau, Honduras, Hungary, India, Indonesia, Iran, Iraq, Ivory Coast, Jordan, Khmer Republic, Kuwait, Lebanon, Liberia, Libyan Arab Republic, Madagascar, Mali, Morocco, Mauritania, Mexico, Mongolia, Nigeria, Norway, Pakistan, Panama, Peru, Poland, Qatar, Republic of Vietnam, Romania, Saudi Arabia, Senegal, Sri Lanka, the Sudan, Sultanate of Oman, Syrian Arab Republic, Thailand, Togo, Trinidad and Tobago, Tunisia, Uganda, Ukrainian Soviet Socialist Republic, Union of Soviet Socialist Republics, United Arab Emirates, United Republic of Cameroon, United Republic of Tanzania, Venezuela, Yemen, Yugoslavia, Zaire and Zambia (Official Records (1974-1977), vol. viii, CDDH/SR.11, 102).

180 The following states voted against: Belgium, Canada, Denmark, Federal Republic of Germany, France, Israel, Italy, Japan, Liechtenstein, Luxembourg, 
abstentions. ${ }^{181}$ In consequence most scholars submit that Article 1(4) does not reflect customary law. ${ }^{182}$

\subsubsection{Additional Protocol II}

According to the ICRC, the starting point of APII was the fact that the majority of armed conflicts since the Second World War had been NIAC, ${ }^{183}$ and that these conflicts had shown that the rules of CA3 needed elaboration and completion. ${ }^{184}$ As the discussions on national liberation movements with regard to API were clouded by political motives related to the Cold War and the decolonisation struggle, extracting states' approaches to the distinction between IAC and NIAC is not an easy task. However, when states started to discuss APII, which was intended to apply in NIAC, their opinions with regard to the distinction between IAC and NIAC became much clearer. ${ }^{185}$

As at the 1949 Diplomatic Conference, several states suggested abolishing the distinction between IAC and NIAC and to form one body of law based on the need to extend humanitarian norms to NIAC. ${ }^{186}$ Nevertheless, this suggestion was supported by an even smaller minority than at the 1949 Diplomatic Conference, ${ }^{187}$ and was not supported by the ICRC (unlike in the 1949 Diplomatic Conference). The ICRC explained its position regarding the distinction between IAC and NIAC: 'In order to take into account the fundamentally different political aspects which existed between international and non-international armed conflicts, the ICRC had respected the distinction, well established in public international law, between those armed conflicts, in conformity with the wish

Monaco, Netherlands, New Zealand, Portugal, Republic of Korea, South Africa, Spain, Switzerland, United Kingdom, United States, Uruguay (see ibid.).

181 The following states abstained: Australia, Austria, Burma, Brazil, Colombia, Chile, Greece, Guatemala, Holy See, Ireland, Philippines, Sweden and Turkey (ibid.).

182 E.g. Dinstein (2010B), 28, [68]. But see Cassese (2008B), 106.

183 Official Records (1974-1977), vol. viii, CDDH/I/SR.22, 201.

184 Ibid.

185 The normative ramifications of APII are briefly discussed in Chapter 2, Section 2.2.2.

186 This opinion was shared by Norway (Official Records (1974-1977), vol. v, CDDH/SR.10, 91), Syria (vol. v, CDDH/SR.18, 193) and to some extent by Sweden (arguing the need to define rules relative to non-international armed conflicts which would closely resemble the rules applicable in international conflicts' (vol. V, CDDH/SR.14, 142)).

187 See discussion on the states that supported the 'Stockholm Proposal' in text at notes 112-119 supra. 
expressed by the vast majority of experts consulted.' ${ }^{188}$ Moreover, the ICRC took this opportunity to articulate the rationale behind the drafting of APII:

With a view to achieving a delicate balance between the needs of humanity and the security requirements of the State intending to take the requisite steps to maintain or re-establish order on its territory, draft Protocol II left intact the right of the constituted authorities to prosecute and sentence persons guilty of offences committed in [connection] with the armed conflict. ${ }^{189}$

Once again, we can see that the law of NIAC was based on the aim of extending humanitarian norms to internal armed conflicts without granting belligerent rights to non-state groups. Even the ICRC acknowledged that states ('constituted authorities') had a right to prosecute non-state group members for participation in armed conflicts in accordance with their domestic law. ${ }^{190}$ The ICRC also acknowledged implicitly the inequality between states and non-state groups in terms of the right to belligerency by stating that the 'draft Protocol II reaffirmed the principle that the legal status of the Parties to the conflict would not be affected by the application of its provision'. ${ }^{191}$ Finally, the ICRC addressed the concern for the principle of states sovereignty and of non-interference in their internal affairs and stated that 'draft Protocol II contained a safeguard clause stating that nothing in the instrument should be interpreted as authorising third states to intervene in the armed conflict' ${ }^{192}$

In continuation of the 1949 Diplomatic Conference, we can see that states' concerns regarding their sovereignty and interference by foreign power served as justifications for the distinction between IAC and NIAC. In this vein, the delegate of the German Democratic Republic stated that the distinction between IAC and NIAC 'was a very important distinction, based on respect for State sovereignty and territorial integrity'. ${ }^{193}$ Furthermore, the delegate argued that internationalisation of NIAC would

\footnotetext{
188 Official Records (1974-1977), vol. viii, CDDH/I/SR.22, 202.

189 Ibid.

190 Though the ICRC did not state explicitly that mere participation in armed conflicts can constitute an offence under domestic law, as this sentence has been stated in connection with states' right to re-establish order, it is reasonable to assume that this was the intent.

191 Official Records (1974-1977), vol. viii, CDDH/I/SR.22, 202.

192 Ibid.

193 Ibid., 206. A similar opinion was articulated by the Romanian delegate who stated "that his delegation attached considerable importance to the field of application of draft Protocol II, since the sovereignty of States was involved.
} 
'encourage interference in the domestic affairs of States'. ${ }^{194}$ Indeed, the concern for the principles of sovereignty and non-interference in internal matters was shared by various states. ${ }^{195}$ The fears of third world states about foreign intervention and the undermining of state sovereignty and the way that the law of NIAC (as distinct from the law of IAC) in APII addressed these fears was summarised by the Egyptian delegation:

Several delegations from the third world had expressed legitimate anxiety, however, about the possibility of Protocol II being used as a justification for intervention. In a world in which threats as well as acts of intervention, military or otherwise, were common, it was important that those misgivings be taken into consideration. Draft Protocol II did endeavour to meet them in general ... Thus, the mechanism of scrutiny of implementation ... was voluntary, and the Protocol did not provide for a prisoner-of-war status ... ${ }^{196}$

The Indian delegation even doubted whether APII was needed in light of the inclusion of national liberation movements in API '.. . since any other conflict taking place within the territory of a sovereign State would be an internal conflict, and any international instrument designed to regulate non-international conflicts might in actual application impede the settlement of the conflict and lead to external interference'. ${ }^{197}$ Indeed, the concern for the principles of sovereignty and non-interference was recognised by the ICRC with the proposal of draft Article 4 (which came to be Article 3), which reaffirmed the principles of state sovereignty and of non-intervention. ${ }^{198}$

To conclude, APII symbolised the clear reaffirmation of the distinction between IAC and NIAC by states and the ICRC. States' concerns for their sovereignty and for their rights to security and to re-establish their authority by defeating non-state groups emphasised the need for a

There was a fundamental difference between international and non-international armed conflicts, and it would be a mistake automatically to transpose the provisions of draft Protocol I to draft Protocol II' (ibid., vol. viii, CDDH/I/SR.23, 221).

194 Official Records (1974-1977), vol. viii, CDDH/I/SR.22, 207.

195 E.g. Argentina (vol. viii, CDDH/I/SR.22, 205), Indonesia (ibid., 212), Italy (recognising the need to 'balance between humanitarian demands and the need to ensure non-interference in the action of the public authorities', vol. viii, CDDH/I/SR.23, 223); Yugoslavia (vol. viii, CDDH/I/SR.24, 230); Mexico (vol. viii, CDDH/I/SR.23, 231).

196 Official Records (1974-1977), vol. viii, CDDH/I/SR.24, 234.

197 Official Records (1974-1977), vol. v, CDDH/SR.29, 345.

198 Official Records (1974-1977), vol. viii, CDDH/I/SR.24, 237; AP Commentary, 1362. 
distinct body of law for NIAC. As explained above, the normative ramifications behind these titles of sovereignty and security were the reaffirmation of the prohibition on foreign intervention and the lack of POW status for non-state group members.

\subsection{CONCLUSION}

We have seen in this chapter that well before the adoption of CA3 of the 1949 Geneva Conventions, international wars and internal wars were two distinct concepts. The former were regulated by religious constraints and then by international law while the latter were not regulated and were considered an internal matter of the sovereign. The theoretical justifications for the distinction between the two conflicts ranged from religiousbased justifications of the right to govern and quell rebellion to the international law principle of sovereignty and security-based justifications. Although the set of justifications has changed throughout the years, the thrust behind the distinction was that sovereigns (kings, princes etc.), and later states, considered NIAC an internal matter and perceived non-state groups that fought against them as criminals who did not have belligerency rights as other sovereigns or states.

Nevertheless, throughout the bloody experiences of states with internal wars, the aspiration to extend humanitarian norms to these wars has become dominant. This aspiration, combined with the conceptual differences, as perceived by states, between international and internal wars yielded the creation of a distinct body of international law that regulated NIAC with the adoption of CA3 of 1949 Geneva Conventions. Although CA3 was a cornerstone in the development of IHL and symbolised the shift of NIAC from the internal sphere of municipal law to the sphere of international law, states maintained their perception that internal and international wars are two distinct types of wars and that the crux of this distinction is that non-state groups do not have belligerency rights and do not deserve POW status. ${ }^{199}$ As was aptly put by Whippman:

States have insisted that non-state actors fighting against a state be treated as either rebels or criminals, and that is why we have different rules for internal armed conflicts and international armed conflicts. Only soldiers fighting for the state in an international armed conflict are deemed to have the combatant's privilege, which is essentially a way of saying that it is not illegal for

199 Other normative ramifications of the distinction between IAC and NIAC are addressed in Chapter 2. 
them to participate in hostilities. They have a right to use force - to use violence against enemy soldiers and enemy forces. ${ }^{200}$

Based on the same line of reasoning, the distinction between IAC and NIAC was maintained in the 1977 Additional Protocols. The distinction between these two types of conflicts is also manifested in the ICC Statute by the different provisions for war crimes committed in IAC and war crimes committed in NIAC. ${ }^{201}$ Although there is a clear pattern of confluence between IAC and NIAC, mainly through customary law but also via treaty law, it is indisputable that as a matter of law, the distinction between IAC and NIAC still exists. ${ }^{202}$

In light of Article 31(1) of the Vienna Convention on the Law of Treaties, which emphasises the importance of the context, object and purpose for the interpretation of treaties, ${ }^{203}$ the willingness of most states to extend humanitarian protection to internal armed conflicts while maintaining the distinction between IAC and NIAC, and - more importantly - the reasons for keeping this distinction, should be kept in mind when we examine the different controversial issues with regard to conflict classification of civil wars with foreign interventions.

200 Whippman (2006), 701.

201 See discussion in Chapter 2, Section 2.3.1.

202 See discussion in Chapter 2, Section 2.3.

203 See Article 31(1) of the Vienna Convention on the Law of Treaties (signed 23 May 1969, entered into force 27 January 1980) 1155 UNTS 113 ('A treaty shall be interpreted in good faith in accordance with the ordinary meaning to be given to the terms of the treaty in their context and in the light of its object and purpose'). 